\title{
FRIEDRICH DANIEL ERNST SCHLEIERMACHER (1768-1834) PEDAGÓGIAI GONDOLKODÁSI STÍLUSA AZ EGYENSÚLY ESZMÉJÉNEK TÜKRÉBEN
}

\section{Szerző:}

Nádudvari Gabriella

Szegedi Tudományegyetem

Szerző e-mail címe:

nadudvari@jgypk.szte.hu

\section{Lektorok:}

Pukánszky Béla (Prof. Dr.)

Szegedi Tudományegyetem

Fizel Natasa (PhD)

Szegedi Tudományegyetem

...és további két anonim lektor

\begin{abstract}
Absztrakt
Jelen tanulmány célja, hogy a Mező-féle OxIPO-modell értelmezési keretében kísérletet tegyen Daniel Ernst Schleiermacher pedagógiai gondolkodási stílusának leképezésére. A tanulmány részletesen vizsgálja az egyensúly eszméjének megjelenését Schleiermacher pedagógiai írásaiban, s ennek tükrében rámutat a jelenünk számára átörökíthető pedagógiai gondolatokra is.
\end{abstract}

Kulcsszavak: Schleiermacher, pedagógiai gondolkodási stílus, az egyensúly eszméje, neveléstörténet

Diszciplinák: pedagógia, történelem

\begin{abstract}
FRIEDRICH DANIEL ERNST SCHLEIERMACHER'S (1768-1834) VIEWS ON EDUCATION AS IT IS REFLECTED IN THE IDEAL OF EQUILIBRIUM

The present paper aims at providing a transposition of Daniel Ernst Schleiermacher's views on education in the interpretation framework of Mező's OxIPO-model. The paper investigates in detail the emergence of the ideal of equilibrium in Schleiermacher's writings on education, identifying pedagogical thoughts transmittable to our present.
\end{abstract}

Keywords: Schleiermacher, views on education, ideal of equilibrium, history of education

Disciplines: pedagogy, history

Nádudvari Gabriella (2019): Friedrich Daniel Ernst Schleiermacher (1768-1834) pedagógiai gondolkodási stílusa az egyensúly eszméjének tükrében. OxIPO - interdisžciplináris tudományos folyóirat, 2019/4, 9-22. doi: 10.35405/OXIPO.2019.4.9 
E tanulmány célja Friedrich Daniel Ernst Schleiermacher (1768-1834), protestáns teológus, filozófus, publicista, kultúrakutató, pedagógus pedagógiai gondolkodási stílusának elemzése az egyensúly eszméjének tükrében, valamint annak megvitatása, melyek azok a Schleiermacherrel kapcsolatos mentalitástörténeti minták, amelyek újragondolása friss felismerések forrásává válhat a posztmodern utáni kor pedagógiai kihívásairól elmélkedők számára.

Sokoldalúsága miatt Schleiermacher korának egyik legbefolyásosabb gondolkodója volt: egy olyan elme, aki nemcsak filozófiai és teológiai témájú írásaival alkotott maradandót, hanem Johann Friedrich Herbart (1776-1841) mellett a pedagógia, mint tudomány egyik megalapítója is volt. Németh és Pukánszky (1997) is kiemeli, hogy a pedagógia rendszerezett tudománnyá válásához a felvilágosodás gondolatvilágán és az abból kibontakozó Wolfféle pszichológián és Rousseau műveinek pedagógiai vonatkozásain kívül a német idealista filozófiai rendszerek, többek között Schleiermacher filozófiája is hozzájárult. Ezen áramlatok részeként a XVIII. sz. második felében mutatkozott meg az igény a katolikus és a protestáns teológiától elkülönülő új törekvésekre, melyek eredményeként egyre pregnánsabban körvonalazódik a pedagógia, mint tudomány arculata. Schleiermacher hermeneutikai irányultságú, dialektikus gondolkodásmódja máig hatással van a szellemtörténeti orientációjú pedagógiára, és jelenünkben is különösen fontos kiegyensúlyozó szerephez juthatna a tisztán empirikus, technológiai neveléstudomány mellett.

Schleiermacher azon kortársai közé sorolható, akik a modern ipari társadalom elleni tiltakozás előfutárai voltak, mely az élmény és a megélni szót a 20. század elején szinte vallásos csengésű jelszóvá tette (Gadamer, 1984). Intenzív recepciója többek között Wilhelm Dilthey (18331911) közvetítő tevékenységének, illetve Leben Schleiermachers c. háromkötetes munkájának (1870) köszönhetően - mind Németországban, mind Magyarországon a hosszú századforduló időszakára tehető. Schneller István Halléban, Ulrici vezetése alatt foglalkozott először behatóbban Schleiermacherrel és általános vallástörténetével (Schneller, 1900). Ugyancsak a hosszú századforduló horizontján Szelényi Ödön rámutat arra, hogy mind sűrűbben hivatkoznak Schleiermacherre (Szelényi, 1910, 1912a, b, c), és a legnagyobb elismerés hangján emlékeznek meg pedagógiai elméletéről. Fuchs (2015) és Ohst (2017) Schleiermacher pedagógiáját újraértelmező műveinek kiadása arról tanúskodik, hogy a német romantika kiváló gondolkodójának pedagógiai életműve ismét tudományos érdeklődésre tarthat számot. Magyarországon Pukánszky (1990, 2018) Schleiermacher Schneller Istvánra gyakorolt hatását vizsgálta.

Tanulmányunk két fő részből áll. Az első részben Schleiermacher 1813-tól 1826ig tartó egyetemi oktatói időszakára jellemző pedagógiai gondolkodási stílusának kialakulását gondoljuk végig a Mező-féle OxIPO-modell (részletesen lásd.: Mező és 
Mező, 2019) értelmezési keretében. E modell szerint (amely alkalmasnak bizonyul történeti témák feldolgozására is v.ö.: M. Pellesz és Szűts-Novák, 2019) a humán információfeldolgozásnak legalább négy komponense van: Organizáció = szervezés, Input = információ bemenet, Process $=$ információ feldolgozás, Output = információ kimenet. Az egyes komponensek ismeretében következtethetünk az ismeretlen változókra (tanulmányunkban elsősorban az input és az output ismeretében következtethetünk a Processre, azaz az emocionális és a kognitív feldolgozás jellegére). A tanulmány második részében az egyensúly eszméjének tükrében vizsgáljuk Schleiermacher Pädagogische Schriften (Pedagógiai irások, ford.: N.G.) c. művét. Manfred Frank A stílus filozófiája c. könyvében (2001) tárgyalt stílusfelfogásából kiindulva, müimmanens elemzésünk során. Frost (2017) kutatási eredményeit is felhasználva, azokat a tartalmi elemeket emeljük ki, amelyek jól láttatják Schleiermacher individuális értelemeffektusait.

Schleiermacher pedagógiai gondolkodási stílusának fejlődéstörténete

Input. A Mező-féle OxIPO-modell (Mező és Mező, 2019) Input (I) komponensének segítségével feltárjuk azokat a bemeneti feltételeket, amelyek hozzájárultak Schleiermacher pedagógiai gondolkodási stílusának kialakulásához. A német idealizmus egyik vezető alakja, Friedrich Daniel Ernst Schleiermacher (1768-1834) lelkész családban született, Boroszlóban.
A különlegesen tehetséges fiú 1785-től 1787-ig a barby-i evangélikus közösség szemináriumában nevelkedett. Az ott megtapasztalt érzelmi élet jellege és minősége meghatározta egész életét, ám korán felébredt vallási kételyei miatt inkább a szabad szellemi életet választotta. 1787-tôl 1789-ig teológiát tanult Halléban. Johann August Eberhard (1739-1809), filozófus és Friedrich August Wolf (1759-1824), filológus egyfelől a görög filozófia tanulmányozására, másfelől Kant filozófiai rendszerének megismerésére buzdította Schleiermachert (Fuchs, 2015). Tanulmányait követő házitanítói és segédprédikátori éveiben szerzett tapasztalatai hozzájárultak ahhoz, hogy rátaláljon saját álláspontjára, melynek lényege a kritikus megfontoltság és a kifinomult gondolkodásmód kiegyensúlyozása a bensőséges vallásos érzelmi élettel. Kant után megismeri Jacobi írásait, és később Spinozát is tanulmányozza. 1796-ban Berlinben megismerkedik az ottani romantikus körrel. Friedrich Schlegellel és Henriette Herz-cel folytatott levelezése plasztikusan mutatja érzékeny kapcsolódását a romantikus szellemiséghez (Meisner, 1922). A későbbiekben Platónért rajong, akinek a mûveit majdnem teljesen le is fordítja. Ezekből az elemekből tevődik össze világnézete.

Process. Az OxIPO-modell (Mező és Mező, 2019) Process elemére, azaz jelen esetben a külső és a belső ingerek kognitív és emocionális feldolgozására az Input elemeiből, továbbá a Schleiermacherhez időben és térben közel álló gondolkodók 
- Rudolf Eucken, Karl Schmidt - mentalitástörténeti fejtegetéseiből és a romantikus gondolkodó pedagógiai írásain kívül első két jelentős írásából következtetünk.

Rudolf Eucken (1905) szerint Schleiermacher nem rendelkezett Hegel, Schelling és Fichte átható, változtató erejével, ám frissességgel és természetességgel olvasztotta be egyediségébe a világ gazdagságának minden hatását. A lélek és a világ közötti kommunikációban kibontakozott nála egyfajta művészi életfolyamat, amely minden merevséget meglágyít, minden sokszínűséget összesző, minden megfogant dolgot megnemesít. Mindenekelőtt csodálatra méltó az a képesség, amely az egyébként a vagy-vagy-ba torkolló - ellentéteket a kölcsönös kiegészítés viszonyába szelídíti. Ebből bontotta ki Schleiermacher a dialektikáját vagy a gondolkodás művészetének tanát.

Mint fentebb is kifejtettük, Schleiermacher világnézetét a spinozizmus is meghatározta, amely korának vezérszellemeit is vonzotta. Itt is megmutatkozott erős vágya a minden ellentéten felülemelkedő egység iránt, kirajzolódott továbbá az az igény is, hogy az egyes ember be tudjon kapcsolódni a mindenség életébe, és érzékelhető a vágyakozás az iránt, hogy a lét a puszta emberi célok fölé emelkedjen. Eucken (1905) úgy véli, Schleiermacher spinozizmusa nem puszta utánzás, hanem sokkal inkább egyfajta, a platóni gondolkodásmód által átalakított spinozizmus. Spinoza merev, minden emberi érzést elutasító rendjébe meleg életet lehel, és egy ilyen életből a valóság egyidejűleg művészi formát is merít. A művészi szabadság és a szellemi rugalmasság megteremti annak a feltételét, hogy a dolgok elidegenítsék maguktól az anyag minden nehézségét. A szellem görög frissessége és bája semelyik nagy gondolkodónál sem éledt újjá úgy, mint Schleiermachernél, aki a vallás és az etika területén jelentőset alkotott, és pedagógiai munkássága is figyelemre méltó (Eucken, 1905).

Első két jelentôs írása Reden über die Religion an die Gebildeten unter ibren Verächtern (A vallásról. Beszédek a müveltekbez megvetöik között, 1799), Monologen (Monológok, 1800) már tartalmazza késóbbi pedagógiai témájú előadásait is átható világnézetének magvát. Elsőként említett műve az örökre és a végtelenre mutat, aminek bennünk lévő érzése a vallást jelenti, míg Monológok c. műve az individualizmust élteti. Miközben kifejezzük önmagunkat, a ránk jellemző módon az emberiséget is ábrázoljuk, és hatunk másokra. Vorländer (1932) szerint ebben a szellemben végezte Schleiermacher stolpei, hallei és berlini prédikátori tevékenységét is.

1804-től a hallei egyetemen, 1810-től a berlini egyetemen folytatott oktatási tevékenysége keretében a teológia mellett a filozófiai tudományok széles spektrumával foglalkozott: dialektikával, etikával, államelmélettel, hermeneutikával, esztétikával és filozófiatörténettel, pszichológiával, pedagógiával, és számtalan, részben részletesen kidolgozott tervezetet hagyott hátra (Lehnerer, 1984). Dr. Karl Schmidt (1860-1862) pedagógiatörténeti művében 
(Die Geschichte der Pädagogik in weltgeschichtlicher Entwicklung und im organischen Zusammenhange mit dem Kulturleben der Völker, A pedagógia története a világtörténelmi fejlödés tükerében és a népek. kulturális életével való organikus összefüggésben, ford.: N.G.) kifejti, hogy a pedagógia filozófiai szemléletének csúcspontja az a kiváló férfiú, aki szellemének sajátosságában és virtuozitásában visszatükrözte a teljes szellemi szférát. Mûvészi szintű tudásával az új teológia megalapítója lett, a filozófiában pedig Schelling és Hegel absztrakcióival szemben a színes életet és annak sajátságait hangsúlyozta. Számára a pedagógia a család, az állam, az egyház és az iskola együttes feladata volt.

Output. Pedagógiai gondolkodási stílusának Output (O) eleme a Mező-féle OxIPO-modell (Mező és Mező, 2019) értelmezési terében Schleiermacher pedagógiai előadássorozata, mellyel Johann Friedrich Herbarttal (1776-1841) együtt a pedagógia, mint modern tudomány megalapítójává vált. Schleiermacher 1813/ 1814-ben és 1820/1821-ben, valamint 1826-ban Berlinben tartott pedagógiai témájú előadásokat.

A német romantika jelentős pedagógiai rendszeralkotójának gondolkodási stílusa, mint a Mező-féle modellben (Mező és Mező, 2019) értelmezett „eredmény” azért tehető vizsgálat tárgyává, mert Schleiermacher előadásai ismert és ismeretlen kezekből származó jegyzetek rekonstrukcióiként rendelkezésre állnak, és ezekben egy világos rendszerező elv fe- dezhető fel. A rekonstrukciót Platz végezte el, aki az 1847-ben írt kiadói előszavában rendkívüli gondossággal ecseteli, hogyan és kitől kapta a kéziratokat. Bár Platz 1849-ben kiadta Schleiermacher pedagógiai munkáját, nem gyakorolhatott termékenyítő hatást szélesebb rétegekre, ugyanis időközben Herbart pedagógiája emelkedett mind nagyobb tekintélyre. A Platzféle munka 1902-ig három kiadást élt meg. Tanulmányunk következő fejezetében a harmadik, langensalza-i kiadásban megjelenő szövegből emelünk ki és értelmezünk olyan szövegegységeket, amelyek jól láttatják Schleiermacher az egyensúly eszméjével áthatott gondolkodási stílusát.

Organizáció. A Schleiermachert érő ingerek (input) feldolgozása (process) és új eszmerenszerbe öntése (ouput) során valószínűsíthetően döntő mértékben spontán tanulásszervezés volt jellemző, amit tudatos, szándékos szervezési epizódok tarkítottak.

\section{Schleiermacher pedagógiai gondol-} kodási stílusának vizsgálata az egyensúly eszméjének tükrében

Schleiermacher pedagógiáról szóló előadásainak belső dinamikája dialektikus gondolkodásmódjának az eredménye. Ellentétes nézeteket, vitatott véleményeket kapcsol be a tudományos diskurzus körébe. E dialektikus eljárás során az akkori jelenben bevonta hallgatóit és bevonja mindenkori olvasóit az általa felvetett problémák kibontásába. Művében felül- 
múlhatatlan reflexiós szinten, csodálatos éleslátással ragadja meg a nevelési cselekvés problémáit a modernitás korában (Fuchs, 2015).

Schleiermacher jelentőségéhez a 20 . század első negyedének horizontján vizsgálódva sem fér kétség. Wilhelm Dilthey közvetítésével jelentős befolyásra tett szert Schleiermacher a szellemtörténeti irányultságú pedagógiára. Szelényi Ödön (1910) a Monológok c. művet az individualisztikus etika rendkívül érdekes dokumentumának tartja, mely nem egy helyütt Nietzschével találkozik, s rámutat arra, hogy filozófiai erkölcstana bővelkedik az eredeti, izgalmas gondolatokban.

A jelenkori filozófiai gondolkodók horizontján vizsgálódva megemlíthetjük Weiß János (2000) Schleiermacher-kutatásait, aki meglepő kijelentéssel kezdi értekezését Schleiermacher etikájáról. Véleménye szerint Kant A gyakorlati ész kritikája c. müvének megjelenése után az etikatörténet következő kiemelkedő eseménye Schleiermacher Brouillon zur Ethik című első rendszeres etikai tervezete, amely voltaképpen a filozófus hallei egyetemi előadásainak vázlata volt.

Weiss (2000) kiemeli, hogy Schleiermacher egyfelől megkísérli elhatárolni magát az ókori etikáktól, másrészt visszautasítja a racionálisnak nevezett kanti és kantiánus koncepciókat is. Az ókori etikákkal szemben az volt a kifogása, hogy ezek nem az ész közegében, hanem inkább az empíria világában mozognak, s ezért sohasem tudnak megfogalmazni szükségszerū tételeket. A kanti etikában viszont a törvény áll a középpontban, ezért bár az ész közegében mozog, formális marad.

E két irányzaton túllépve vagy ezeket harmonizálva, Schleiermacher az ész interszubjektív szemléletét próbálta kimunkálni. Az interszubjektív etika a „létrehozás" momentumát helyezi középpontba. Ezt a koncepciót a „létrehozás dialektikájának" nevezi Weiss (2000), aki szerint a dialektikus gondolkodás Schleiermachernél két pólus feszültségtartományában bontakozik ki:

1. Schleiermacher organizmusnak nevezi az első pólust. Az organizmus az emberi lét nyitottsága a rajta kívül álló léttel szemben. Ez a pólus Schleiermachernél a benyomásokkal azonos.

2. A másik pólust a gondolkodás, mint intellektuális tevékenység képezi, amely a puszta gondolkodási aktus szemléletére épül.

Schleiermacher kijelenti, hogy nincs okunk rá, hogy e két tevékenységet az életben valóban elkülönítsük egymástól. A két pólus ugyanis áthatja egymást, és létrejön az „abszolút tudás”. Ebben a tudásban ötvöződnek a különösség (organizmus) és az általánosság (intellektuális tevékenység) mozzanatai (Weiss: 2000).

Ezt a gondolati struktúrát alkalmazza Schleiermacher az „erkölcsiség” vizsgálatakor. Az erkölcsiség maga is különleges gondolati tevékenység. Az erkölcsiségben az organizmus a „legfőbb jó” formájában, az intellektuális tevékenység az erények formájában jelenik meg. E kettő szintézise pedig a kötelességek fogalmát képezi. En- 
nek alapján értelmezhető a schleiermacheri etika felépítése (Weiss: 2000).

A legfőbb jó schleiermacheri felfogását Weiss (2000, 85. o.) így fogalmazza meg: „A »legfőbbet« nem komparatív, hanem a totalitás értelmében kell felfognunk, a »jó« pedig annak affirmációja, ami az ideákban rejlik." Ez a megfogalmazás Weiss (2000) szerint úgy értelmezhető, hogy a legfőbb jó mindig valamely komplex értelemben vett ideális tartalomra irányul.

Az erény Schleiermacher számára az erkölcsiség az egyes ember szempontjából tekintve. Az erények az orgánumok kialakulásának lehetőségfeltételei (lásd: Weiss, 2000).

A kötelességet általában úgy szokták definiálni, hogyha ennek eleget teszünk, erényessé válhatunk. Schleiermacher rendszerében az erényeknek nincs leíró jellegük, ezért a kötelesség fogalma is új értelmet nyer. Az ember nemcsak megteremti a kollektív interszubjektív világot, és nem egyszerűen önmagában rendelkezik az erkölcsiséggel, hanem a kettő szintézisét végre kell hajtania. Ez az ember kötelessége (Weiss, 2000).

$\mathrm{Az}$ interszubjektivitás akkor kerül veszélybe, ha a társadalmi-történelmi világban a tényszerűség lép a létrehozás helyébe. A tényszerűség a schleiermacheri dialektikus konstrukció szétesését feltételezi, s ez a szétesés kétféle elvi veszély forrása lehet: az intézmények megszilárdulása és a közösségi és személyes erkölcsiség bomlása (Weiss, 2000).

Schleiermacher szerint a pedagógia az etika részterülete, miként a politika is.
„Mindkét elmélet, a pedagógia és a politika teljes mértékben hat egymásra; mindkettö etikai tudomány, és azonos módon kell kezelni öket" (Schleiermacher, 1902, 9. o., ford. N.G.). Mindkettőt a jó cselekvés elméleteként értelmezhetjük. A pedagógia az érett és felelősséget vállaló emberek és a felnövekvő emberek között megvalósuló cselekvés, melynek célja, hogy a felnövekvők a nevelés és a képzés által össztársadalmi szempontból értelmezett érettségre és felelősségre tegyenek szert, és egy magasabb erkölcsi szintre jussanak. A politika az érett és felelős felnőttek körében értelmezett cselekvés, társadalmi kontextusban. Schleiermacher a politika és a pedagógia egymásrautaltságáról beszél, illetve arról, hogy kölcsönösen függ az egyik a másiktól. A nevelés révén lehet megszerezni a politikai cselekvés képességét, és csak ez által válik lehetségessé a politikai nyilvánosság és gyakorlat. A politika ebben az értelemben a neveléstől és a képzéstől függ. Ha más irányból közelítjük meg a problémát, a politika nyitja meg - vagy zárja el - a nevelés és a képzés lehetőségeit és játéktereit. Frost (2017) is rámutat arra, hogy Schleiermacher gondolatrendszerében egy közélet sikeres erkölcsisége azon mérhető le, mennyire jól koordinált a pedagógia és a politika, és mennyire segíti egymást a két rendszer, oly módon, hogy a pedagógiai jó és a politikai jó öszszekapcsolódik. Ha ez megtörténik, egy olyan egyensúlyállapot jön létre, melyben a politika értékei és normái olyanok, hogy azok nevelési és képzési célokként etikai szempontból is vállalhatók, illetve a neve- 
lés és a képzés értékei a politikában ténylegesen le is csapódnak.

Schleiermacher úgy véli továbbá, az emberi életben nem találjuk meg a tökéletességet, mert az emberi élet csak egyfajta közelítés a tökéletességhez. Mindazonáltal minél tökéletesebb a nagy életközösségek szerveződése, annál nagyobb a harmónia az egész és közösségek egyes tagjai között, és annál kevesebb ellenhatást kell gyakorolnia a nevelésnek. Ez fordítva is igaz. Itt is tetten érhető az egyensúly elve: Amilyen mértékben csökken a pedagógiai ellenhatás szükségessége, olyan mértékben nő a támogató pedagógiai magatartás lehetősége. „Minél tökéletesebb az össz-állapot, annál kevésbé szülkséges, hogy a támogatás tudatos és módszeres legyen, mert abol a nagy életközösségek teljes mértékben morálisan alakulnak ki, harmóniának kell lenni köztük, (...)" (Schleiermacher, 1902, 64. o., ford. N. G.). Egy ilyen „össz-állapotban” az állam, az egyház, a társas élet és a tudás területén minden erkölccsé válik. Schleiermacher (1902, 64. o., ford.: N. G.) szerint: ,ha ez az állapot fennmaradna, az idösebb generációnak a fiatalabb generációra gyakorolt hatása nem lenne más, mint egy olyan erkölcs kiáramlása, amely különleges elmélet és módszer nélkül tud létezni; (...)”. Ez a hatás egy olyan, az erkölcsiség eszméjének megfelelő viselkedés lenne, amely az idősebb generáció fiatalabb generációval való bánásmódját jellemezné. E közösségek tökéletességét két momentum teremti meg: 1. a forma tökéletessége (alkotmány, állami berendezkedés), 2. az egyes (ember) megfelelése az egésznek. Minél inkább egyensúlyban van e kettő, annál tökéletesebb az állapot. $\mathrm{Ha}$ nem valósul meg ez a tökéletes állapot, szükségessé válik a nevelés. Minél nagyobb az űr az egyes (ember) és az egész eszméje között, annál szükségesebbé válik a nevelői ellenhatás. Minél kevésbé tökéletes az alkotmány, annál nagyobb szükség van arra, hogy a fiatal generáció közelébe kerüljön valami, ami a tömegben nem lelhetô fel, s mindez azért, hogy az alkotmány tökéletesebb legyen. Schleiermacher voltaképpen kiegyensúlyozza az erkölcsös és a forradalmár ellentmondását, amikor azt írja: „A nevelést úgy kell kialakitani, hogy mindkettó a legnagyobb harmóniában legyen, (...)" (Schleiermacher, 1902, 32. o.; ford.: N.G.). A fiatalságnak ügyesen kell kapcsolódnia a készen találthoz, azaz a kulturális örökséghez, és ugyanolyan ügyesen, erővel kell hozzálátnia a feltáruló hiányosságok javításokhoz.

Schleiermacher 1826-os pedagógiai előadássorozatán a pedagógia tudományként való újjáalapítását azzal kezdi, hogy a nevelői feladatot megfosztja szakma jellegétől. Ennek alapján a pedagógia nem szülőknek vagy tanároknak szóló speciális elmélet, hanem sokkal inkább egy általános érdeklődésre számot tartó, alapvető problémát vet fel: a generációváltást. „Tulajdonképpen mit akar kezdeni az idösebb generáció a fiatalabb generációval? Hogyan fog megfelelni a tevékenység a célnak, az eredmény a tevékenységnek? Az idösebb és a fiatalabb generáció viszonyára, nevezetesen arra, hogy milyen kötelessége van az egyiknek a másikekal szemben, alapozunk mindent, ami ezen elmélet területébez. tartozik" (Schleiermacher, 1902, 5. o., 
ford.: N.G.). A generációváltás a kultúra és a társadalom rendkívül érzékeny töréspontja, mert itt a korábban megteremtett forog kockán, és a jövőbeli fejlődés válik kérdésessé. Az ember kultúrára és történelemre való nyitottsága szempontjából szükség van tradíciókra és intézményekre, melyek azonban a felnövekvő generáció által megkérdőjeleződnek vagy megváltoznak. A kultúrának és a társadalomnak két lehetősége van: vagy a magasabb szintre emelkedés vagy a bukás. Schleiermacher e tekintetben is egy egyensúlyi rendszerben értelmezett növekedésről és csökkenésről beszél. Frost (2017) e kérdéskörre vonatkozó elemzésében külön kiemeli, hogy ha egy társadalom tagjai valamit értékesnek, továbbvitelre érdemesnek tartanak, akkor nem lehet a véletlenre bízni, hogyan viszonyul ehhez a felnövekvő generáció. Ennek alapján a nevelés közös érdek, és ez nemcsak a szülőket és a tanárokat érinti, hanem az egész idősebb generációt, mint politikailag teljes mértékben felelős személyeket. Ez egyfajta reflexiós kultúrát feltételez, melyben a nevelés célkitűzései, cselekvési módjai és eredményei ütköznek egymással. E nevelési reflexióba be kell vonni minden intézményt, csoportot, individuumot.

Frost (2017) értelmezése szerint Schleiermacher a pedagógiát, mint tudományt etikailag alapozza meg, mert a felelősség mértékének a jó kérdését teszi meg. Számára az etika reáltudomány, hiszen a jót nemcsak, mint kell-igényt kell megalapoznia, hanem hozzá kell járulnia a megvalósuláshoz is. A jó egy vezéreszme, amely nem határolható el a történelemtől, a kultúrától és a társadalomtól. Schleiermacher abból indul ki, hogy az ilyen célok akkor valósulnak meg, ha a feszültséggel teli ellentétek (a természet és az értelem, az individuum és a közösség) az értelmes és tapintatos egyesülés folyamatába terelhetők (Frost, 2017). Schleiermacher szemléletmódja értelmében az etika azt mondja meg, hogyan kell egy társadalom intézményeit a humanitás szellemében strukturálni és vezetni. Az etika ily módon a modern kultúra filozófiája, mert azt kutatja, hogyan lehetséges a modernitás körülményei között az ön- és világművelés (Frost: 2017).

Schleiermacher abból indul ki, hogy az ember egy olyan lény, aki önmagában hordozza fejlődésének elegendő okát életének kezdetétől a kiteljesedéséig. Ezt a szellemi élet fogalma implikálja. „Ahol nincs meg az ilyen belsö ok, nem váltorite a squbjektum, vagy csak mechanikusan változike" (Schleiermacher, 1902, 6. o., ford.: N.G.). A romantika szellemében Schleiermacher az embert, mint időben létező és valamivé váló lényt állandó változásban, folyamatban lévőnek írja le, aki „sqigorúan véve egyik pillanatban sem ugyanaz, ami korábban volt; a belsö élettevékenység is ki van téve a változásnak" (Schleiermacher, 1902, 52. o., ford.: N.G.). Ez a szubjektum külső hatásokra (közösség, világ) történő fejlődését is jelenti. A belső fejlődési elv és a külső hatások közötti relációk végtelenül különbözőek lehetnek.

Schleiermacher azokkal a kérdésekkel is foglalkozik, hogy milyen hatást kell kivál- 
tania a pedagógiának, illetve hogy milyen hatást tud kiváltani a pedagógia. Az antropológiai előfeltételek kérdése dönt a pedagógia hatalmáról vagy tehetetlenségérôl. Itt arról van szó, eleve adottak-e, és ha igen, mennyiben adottak az individuális képességek és tulajdonságok fejlődési lehetőségei, vagy ezek a nevelés függvényei. Schleiermacher úgy véli, nem válaszolható meg e kérdés definitív módon, hiszen sem elvekből nem lehet levezetni a választ, sem pedig tapasztalati úton nem lehet magyarázatot adni. E kérdésben is a harmonizáció elve mellett dönt Schleiermacher, amikor kimondja, hogy a nevelés, a közösségek és a társadalom hatása a fiatal emberekre nemcsak legitim, hanem elengedhetetlen is, mert a már kialakult szociális és kulturális szint a személyes kibontakozást döntő módon támogatja, és az egyes embert összekapcsolja a világgal. Ebben az ember spontán és befogadói meghatározottságában mind individuumként, mind közösségi lényként megmutatkozik (Frost, 2017).

Az önkibontakozás és a külső hatás viszonyának úgy kell változnia a nevelés során, hogy kezdetben a ráhatás, később az öntevékenység domináljon. A nevelés célja nemcsak a személyiség kibontakozása kell, hogy legyen, hanem egyben a társadalmi erkölcsiség megvalósulásáért történő felelősségvállalás is. Ebben az értelemben mondja ki Schleiermacher, hogy a fiatalt az államnak és a társadalomnak kell nevelni. A nevelésnek azonban nemcsak a tradíciókat és a vívmányokat kell továbbvinnie, nemcsak a meglévőt kell szolgál- nia, hanem lehetővé kell tennie a kritikát is, és élő, jobbító folyamatban való cselekvésre kell felszólítania (Frost, 2017).

Frost (2017) a schleiermacheri pedagógia szívének nevezi a nevelési tevékenységekről szóló tanítását. Schleiermacher a nevelői cselekvés három alapformáját különbözteti meg: megóvás, ellenhatás és támogatás. A megóvó tevékenység védi a gyermeket a káros külső hatások ellen, mindazonáltal Schleiermacher nem támogatja - Rousseau-val ellentétben - az alapvetően izoláló nevelést, hanem a társadalmi realitással való konfrontációra hív fel, olyan mértékben, amilyen mértékben ezt a gyermek képességei megengedik. Schleiermacher egyensúly-eszméje egészen különleges formát ölt, amikor arról értekezik, hogy a nevelésnek az élethez kell állnia. Ha valami túlzottan tökéletes formát ölt, merevvé válhat, s a túlzott merevség miatt eltörhet. „Ha a teljes élet azonosulna a neveléssel, ha a környezet harmóniaban lenne a nevelés eszméjével, ak.kor is kétséges volna a siker, hiszen a friss, a szabad, az éló, a közvetlen eltünne. Ha a szabadság, az akarati tevékenység - amennyiben az eredeti és személyes nem lehet egy általánosan definiált rend ellenfénye, akekor nem növekedhet; ily módon fejlödése nem zavartalan" (Schleiermacher, 1902, 76. o., ford.: N.G.). Ha megvalósulna a teljes megóvás rendszere, akkor az, ami az egyik oldalon nyereség lenne, elveszne a másik oldalon.

Schleiermacher az idő viszonylatában is megfogalmazta a megóvás maximáját. A nevelés végének az ideje annak a belátása, hogy a nevelt milyen helyet foglal el az 
életben, és hogy milyen fokú az akaratereje. Az erénynek és az értelemnek megfelelő módon fejlettnek kell benne lennie. Amennyiben például az egyén nem ismeri a gonoszt, amely a közös élet eszméje ellen hat, az a belátás hiánya. „Ha a nézete belyes, ez olyan mértékben lesz, az, amilyen mértékben az egész eszméje felébred benne, és a haro tudatosul benne; ha bianyzile belöle a gyakorlat és a küzdelem, akekor az élet olyan harc elé állitja, melyhez. még nem nött fel" (Schleiermacher, 1902, 78. o., ford.: N.G.).

A nevelésnek mindig akkor kell ellenhatást gyakorolnia, amikor a gyermeki cselekvésben felüti a fejét a gonosz. Nem tartja döntő momentumnak Schleiermacher, hogy a gonosz a gyermekben eleve meglévő vagy kívülről jövő. „Ha ezt az élet folyásában, az idöbeliségben, a valamivé válásban szemlébjük, azt kell mondanunk, hogy az, amivé a neveléstöl eltekintve a nevelt minden pillanatban válik, két faktorból áll: a bensô életeröböl és a kivülröl rá ható eröböl. Ez egy adott helyzet, amiher. kapcsolódni tud a nevelés. Azonban mivel az idöbeliség területén mindenütt, ahol a kettösség adott, lehetetlen egy abszolút egyensúly létrejötte, ott, ahová a nevelésnek mindenkor kapcsolódnia kell, hol inkább a nevelt belsö tevékenységét, hol pedig a külsö hatást ami vele történik vagy megtörtént - kell figyelembe venni" (Schleiermacher, 1902, 61. o., ford.: N.G.). Mivel mind a benső tevékenységben, mind a külső hatásban jelen lehet a jó és a gonosz, feltételezhetjük, hogy a nevelt benső tevékenységében hol a támogató, hol a gátló hatás igénye lép fel. Ugyanígy van ez a külső hatás tekintetében is: hol támogató, hol gátló pedagógiai tevé- kenységet célszerű gyakorolni. Ebben a konstellációban is az egyensúly eszméjének érvényesülését fedezhetjük fel.

Frost (2017) az ellenhatás problémaköre kapcsán kifejti, hogy Schleiermacher rendszerében a nevelői hatás csak a cselekvések kivitelezésére, jobb esetben az artikulált cselekvési szándékokra lehet hatással, de az akarat képződésére soha, mert ez a szubjektum saját öntevékenységéhez kötődik. A büntetéseknek azért van csak korlátolt értelmük, mert a gyermek akaratát csak szankcionált cselekvésre tudják irányítani. Értelmesebbnek tűnik az alternatívák felmutatása, amelyek pozitív cselekvési impulzusokhoz kötődnek. Ily módon a támogatás a legfontosabb nevelői tevékenységgé válik, mert a gyermek szabad, önálló cselekvését segíti elő.

Schleiermacher fontos jelentőséget tulajdonít a pedagógiának. Argumentációjában nem a modern mindenhatóságfantázia érződik, hanem annak a nagy felelôsségnek a belátása, amely az erkölcsös életalakítás szempontjából a pedagógia számára adott. Itt bizonyíthat a humanitás:

„A nevelés elmélete az az elv, amiböl minden erkölcsi tökéletesedés megvalósulásának ki kell indulnia. Az emberi élet számára, az egész emberi képzés sqámára nincs jelentösebb, mint a nevelés tökéletessége. A nevelésben elkövetett bibák erösitik az emberi tökéletlenségeket. Ha már nem hibázná el az ember a nevelésben a helyes utat, akekor minden nehézség eltünne, ami az emberi köäösségek minden területén oly könnyen megjelenik" (Schleiermacher, 1902, 34. o., ford.: N.G.). 


\section{Összegzés}

Miként fenti elemzésünkből is kitűnik, s már Szelényi (1912c) is utalt rá, Schleiermacher a pedagógiában az etika próbakövét látta, ahogyan a nevelés elmélete számára a nevelői gyakorlat is próbakő. Szelényi Ödön (1912a) Schleiermacherről szóló trilógiájának első részében Schleiermacher személyére és a kor eszméire fókuszálva értelmezi az „Isten kegyelméböl való pedagógus" (Szelényi, 1912a, 194. o.) neveléstani hagyatékát, hiszen ,elmélete szorosan összefügg személyiségével, melyböl eredt és a korral, melyben irónk élt és müködött és melynek szellemi arculata félreismerhetetlenül tükrözódik annak tartalmában és formájában egyaránt" (Szelényi, 1912a, 195. o.). Szelényi is rávilágít arra a kulturális kontextusra, melynek modell-értékű képviselője Schleiermacher: „Igazán új világot fedeznek tehát föl azok, akik az ésszel szemben a squivakarat és képzelet jogaira bivatkoznak - akik sejtik, hogy az emberi és a történeti élet nem puszta mechanizmus -, hanem organikus fejlódés és ezért megbecsülik a fennálló intézményeket, belyesen értékelik a multat, belepillantanak a müvészet és vallás titkaiba és hangoztatják a geniális és individuális elemek fontosságát" (Szelényi, 1912a, 196. o.). Személyisége kapcsán kiemeli, hogy Schleiermacher a nemes, tiszta erkölcsi alapon nyugvó individualizmus egyik kiváló képviselője: „konciliáns békeszerető jellemsajátsága megóvta a végletektól, amiért csak természetszerü, hogy filozófiájában, teológiájában és pedagógiájában egyaránt közvetitönek bironyul és sokszor igazi müvészkedéssel az ellentétes álláspontok kiegyeztetésén fáradozik" (Szulényi, 1912a, 200. o.). Szelényi Schleiermacher pedagógiai munkásságát kritikusan elemzô trilógiáját azzal a gondolattal zárja, hogy Schleiermacher korának filozófusaihoz hasonlóan „az általánosból indul ki (deduktive halad) és az általános elvekbe belefoglalja a valóságot is. Különös ismertetöjele, hogy egymást kereszৃtezoo" ellentéteket felosz̧tási alapul szeret alkalmazni, az ellentéteket aztán szintézisbe hozza és ezzel a reális valósághoz közeledik." (1912c, 333. o.).

Schleiermacher képes volt a kritikus megfontoltság kifinomult gondolkodásmódját kiegyensúlyozni a bensőséges, vallásos érzelmi élettel. Pedagógiáját áthatja az egyensúly eszméje, ami folytonos hivatkozás az Abszolútum jelenlétére. Monológok (1918) című filozófiai művében elismeri, hogy minden ember a maga sajátos módján képviseli az emberiséget, elemeinek sajátságos keverékében, hogy minden módon megnyilvánuljon, és minden valósággá váljon, ami ölének gyümölcse. Schleiermacher a pedagógia legnemesebb feladatának azt tartja, hogy minden embert az Istenség kiválasztott eszközévé formáljon. „Az örök ember-volt fáradhatatlanul önmaga megteremtésén munkálkodik, és azon, hogy a véges élet múló jelenségeiben a legsokoldalúbban jelenitse meg magát" (Schleiermacher, 2000, 52. o.).

\section{Irodalom}

Dilthey, W. (1870). Leben Schleiermachers. Druck und Verlag Georg Reimer, Berlin. Letöltés: 2019. 10 4. Web: https://archive.org/details/a57398420 $\underline{\text { Odolluoft }}$ 
Eucken, R. (1905). Lebensanschaunngen großer Denker. Verlag von Veit \& Comp, Leipzig.

Fuchs, B. (2015). Friedrich Schleiermacher. Einfübrung mit pädagogischen Texten. Ferdinand Schöningh, Paderborn.

Frank, M.(2001). A stílus filozófiája. Janus/Osiris, Budapest.

Eucken, R. (1905). Lebensanschaunngen großer Denker. Verlag von Veit \& Comp, Leipzig.

Lehnerer, Th. (1984). Einleitung. In: Schleiermacher, F. D. E. (1984): Aestheik. Über den Begriff der Kunst. Felix Meiner Verlag, Hamburg. VIIXXXVIII.

Meisner, H. (Hrsg.) (1922). Schleiermacher als Mensch. Sein Werden und Wirken. Familien- und Freundesbriefe. Verlag Friedrich Andreas Perthes, Gotha.

Mező, F. és Mező, K. (2019). Az OxIPOmodell - az interdiszciplináris kutatások egy lehetséges értelmezési kerete. OxIPO-interdiszciplináris tudományos folyóirat, 2019/1, 9-21. doi: 10.35405/OXIPO.2019.1.9

M. Pellesz, N. és Szűts-Novák, R. (2019). A Pedagógiai és Lélektani Intézet 1929-es megalapítása, szellemi előzményei és múködésének első évtizede - Imre Sándor és Várkonyi Hildebrand Dezső tevékenysége. OxIPO - interdiszciplináris tudományos folyóirat, 2019/2, 9-24. doi: 10.35405/OXIPO.2019.2.9

Németh, A. és Pukánszky, B. (1997). Paradigmatikus irányzatok a magyar neveléstudomány fejlődéstörténetében. Magyar Pedagógia, 97. 3-4. 303-317.
Ohst, M. (Hrsg.) (2017). Schleiermacher Handbuch. Mohr Siebeck, Tübingen.

Platz, C. (Hrsg.) (1902). Schleiermachers pädagogische Schriften. Mit einer Darstellung seines Lebens. Hermann Beyer \& Söhne, Langensalza.

Pukánszky, B. (1990). Schneller István. Országos Pedagógiai Könyvtár és Múzeum, Budapest.

Pukánszky, B. (2018). Német egyetemi filozófiai hatások Schneller István morálpedagógiai rendszerében. In: gerundium 2018/1/2., 23-33. DOI 10.29116

Schleiermacher, F. (1918): Monologe. Verlag von Philipp Reclam, Leipzig.

Schleiermacher, F. D. E. (1985). Über die Religion. Reden an die Gebildeten unter ibren Verächtern. Philipp Reclam Junior, Stuttgart.

Schleiermacher, F. D. E. (2000): A vallásról. Osiris Kiadó, Budapest.

Szelényi, Ö. (1910). Schleiermacher vallásfilozófiája. Corvina nyomdában nyomtatott, Békéscsaba.

Szelényi Ö. (1912a): Schleiermacher pedagógiája. (Első közlemény) In: Magyar Paedagogia. 193-205.

Szelényi Ö. (1912b). Schleiermacher pedagógiája. (Második közlemény) In: Magyar Paedagogia. 272-282.

Szelényi Ö. (1912b). Schleiermacher pedagógiája. (Harmadik, befejező közlemény) In: Magyar Paedagogia. 321-333.

Vorländer, K. (1932). Geschichte der Philosophie. Gustav Kiepenhauer Verlag, Berlin-Charlottenburg. 
Weiss J. (2000). Mi a romantika? Dianoia, Wentscher, E. (1928): Die ethischen Jelenkor Kiadó, Pécs.

Grundlagen von Schleiermachers Pädagogik. Hermann Beyer\&Söhne, Langensalza. 